\title{
Fundamental and technical analyses for stock investment decision making
}

\author{
Layyinaturrobaniyah ${ }^{1,{ }^{*}}$, Dian Masyita ${ }^{2}$, Gilang Sekartadjie ${ }^{3}$ \\ 1, 2, 3 Padjadjaran UniversityBandung, Indonesia
}

\section{Keywords:}

Investment

Stock

Technical analysis

Fundamental analysis

Received: 21 October 2015

Accepted: 16 December 2015

Published: 22 February 2016

\begin{abstract}
This study is aimed at reviewing fundamental variables, and technical factors that have been considered in stock investment decisions as well to determine which of the two approaches is more dominant. The study employed factor analysis and compared means test using sample of investment managers and individual investors in Bandung. About 100 respondents were propagated using proportional random sampling. This study found that almost all of the fundamental factors play role in the investment decision, including interest rate, ratio of profitability, leverage ratio, dividend payout ratio, and asset turnover ratio. While among the technical variables, the historical data analysis is the major consideration. With regard to the selection of preferred approach, the observation indicates that none of the analysis is more dominant.
\end{abstract}

(C) 2016 The Author(s). Published by TAF Publishing.

\section{INTRODUCTION}

Capital markets are influenced by several factors, including uncertainty in the future domestic macroeconomic circumstances and the world monetary state. These factors as well as many other factors make those prices in the stock market fluctuate. Not to mention that the risk of failure cannot escape any investment decisions due to the uncertainty in the future. It requires the investor to know the various kinds of information. The information obtained can be used as reference materials used by decision makers in analyzing investment before making a decision. The purpose of the analysis is to perform a strategy in the selection process and decision-making. There are two main methods that can be used as an analytical tool for investment strategy, the fundamental and technical analyses. Various paradigms began to take shape due to

\footnotetext{
* Corresponding author: Layyinaturrobaniyah
}

E-mail: callista_first@yahoo.com differences of opinion on both the analysis. Fundamental analysis and technical analysis are two main approaches to investing in the stock market. Fundamental analysis is a process with a long enough period of time to investigate the state of the economy, politics, social, industrial and financial statements of the company. Fundamental is essentially historical analysis of the financial strength of a company, where the process is often referred to as the analysis of the company (company analysis). Technical analysis is one method of analysis or approach that evaluates the movement (trend) by studying past market data, primarily price and volume movements to predict price movements in the future. The analyst conducted a study using the chart where they hoped to find a pattern of price movements so that they can exploit for profit. Beside, which is the subject of research is the misconception in the use of fundamental and technical information as a reference in making investment decisions short-term or long-term. There are some investors who are still using the fundamental information for short-term and long-term 
investment. Misinterpretation is because investors lack sufficient knowledge about the use of technical analysis because sometimes there is a gap of teaching material which is dominated by fundamental analysis in the academic sphere (Flanegin \& Ruud, 2005).

However, technical analysis is now becoming a popular method of analysis among investors. Seen from the facts, it is indicated that the availability of this analysis on each monitor stock trading that is also available on various popular technical analysis software, such as Yahoo Finance, Stock Meta and Meta Trader, included analyst recommendations based on technical analysis. Research conducted by (Aprillianto, Wulandari \& Kurrohman, 2014) suggests that investment decisions tend to be influenced by stock analysis techniques. Then Pring (2002) adds to the conclusion that the previous price data can be used to predict future prices and investors have the possibility to obtain results above normal profits. Further research conducted by (Lee et al., 2010) studied about how the investment behavior and decisions of factors affect the performance of the stock market and suggested that technical analysis is more popular as the investment managers felt technical analysis to be more important today. Based on the reason above, each investor needs to conduct fundamental and technical analyses of the various factors that are important before making an investment decision on the stock to reduce investment risk. Also reviewing the results of several previous studies still shows differences in the results of the analysis of the factors that can influence investment decisions. This study intends to examine more deeply the role of the factors used by the decision makers that in this case is a factor of fundamental and technical analyses on the stock investment decisions.

\section{Research Question}

Based on research background as previously described, the proposed formulation of the problem (research question) in this study was to determine the fundamental and technical factors that are considered in stock investment decisions, and determine which investment strategy (fundamental/technical) is more dominant in the stock investment decisions.

\section{Research Purposes}

The purpose of this study is to examine and determine the fundamental and technical factors that are most instrumental and considered in the implementation of stock investment decisions. It is also aimed to know the strategy of stock analysis (fundamental/technical) which is more dominant in the stock investment decisions.

\section{Application of Research}

The usefulness of this study is as follows:

1. Theoretically, to contribute information to the academics, or interested parties regarding the scope of the fundamental and technical analyses in the stock investment decisions.

2. Practical contribution, for market participants expected that this study can be used as input in observation, assessment and determination in making investment decision.

\section{LITERATURE REVIEW}

\section{Investment}

Investment is the purchase of assets that are expected in the future to be resold at a higher value. According to (Bodie, Kane \& Marcus, 2014:1) the investment is a current commitment of money or other resources that are expected to earn profit. Furthermore (Gitman, 2006:332) explains that the investment (long-term) or capital expenditure (capex) is a commitment to spend a certain amount at the present time to allow the company to receive benefits in the future.

As it is known that there are different types of investments, each investment has its own characteristics such as rate of return (return), the level of risk (risk), and the rules of the mechanism. In general types of investments are classified into two categories, namely investment in tangible assets (real assets) and investments in financial wealth (financial assets). Investment in real assets (real assets), namely investment in land, buildings, machinery and knowledge that can be used to produce goods and services. While investment in financial assets (financial assets) are like stocks and bonds (Bodie et al., 2014:2).

\section{Investment Strategy}

Even in simplest investment, a strategy is needed. Moreover, in playing the stock, a stock investment strategy is needed not only for the issue of profit and loss, but to achieve the maximum as well. In determining the investment strategy, the thing that needs to be considered and observed is an investment goal. In effort to fulfill the objectives to be achieved in a stock market investment, we should take various analyses to study and predict the movement of stock prices and the factors that affect stock price movements. In general, there are two kinds of 
approaches in an effort to predict stock price movements that are fundamental analysis and technical analysis.

\section{Fundamental Analysis}

Fundamental analysis is how to use the earnings and prospects of the company's dividends, interest rate expectations in the future, and evaluation to determine the risk of the company's stock price (Bodie et al., 2014:237). Fundamental analysis rests on the belief that the value of a stock is influenced by the performance of the company that issued the stock. If the fundamentals of a company have increased, the estimated price of the stock will have a good performance, then the positive market reaction will be characterized by an increased demand for the company's stock, and it will also affect the stock price to rise. The fundamentals of a company rest on historical data of the company which is reflected in the financial statements of the company. Broadly speaking, there are five main categories of ratios on the company's financial statements, among others, namely: profit (profitability), price (price), liquidity (liquidity), leverage, and efficiency.

Presented by (Brown, 2003:369) regarding the steps that must be done in selecting stocks, the step that must be done first is a top-down analysis, to analyze the state of the economy and the market as a whole. Economic circumstances referred to in these indicators are often used in fundamental analysis such as exchange rate, GDP, inflation, etc. The aim is to determine how to allocate investment funds in a country with various forms of investment, such as in bonds, stocks and cash. Second, there is industry analysis in order to determine which industries will grow up or down, based on the analysis of economic conditions and market earlier. Finally, after determining the industry's best, investors choose stocks of a company that is still considered to be low (undervalued) and evaluate the performance of the company.

\section{Technical Analysis}

Technical analysis is an investment approach by means of observation of historical data. The technical analysis does not take into account the macro-fundamental factors (such as economic growth, the company's sales growth, profit growth, the development of interest rates). Technical analysis is the analysis of market data published on both the stock price and the aggregate of individual stocks, based on the statement "that the use of the published analysis of data of both aggregate market stock prices and individual stocks" made by Jones (2004). While
(Tandelilin, 2010:392) stated that technical analysis is a technique to predict the direction of movement of the stock price and other stock market indicators based on historical market data such as price and volume information.

Technical analysis uses published market data such as stock prices, stock price index either individually or in combination, as well as other factors that are technical. In this technical analysis the main factor is price movements, where the price movement will then be linked to the events of that time such as the influence of economic, political, trade, and other issues. Targets to be achieved in this analysis is the timeliness in predicting the price (price movement). Short-term stock is, therefore, the information derived from technical factors that are very important for investors in determining when to buy and when to sell securities.

\section{METHODOLOGY}

This research applied quantitative approach. Quantitative research is empirical research to obtain data in the form of numbers, with facts and phenomena that have an objective reality and can be measured (Sugiono: 2003). While the approach will be done by using the survey, the data will be collected from a sample of a population by using a questionnaire.

\section{Scale}

This study uses an ordinal scale, the scale of which sorts the data from the lowest level to the highest level (Sekaran, 2006:56). The measurement scale used in this study is the Likert Scale. Below is a table of scores compiled from the answers of the questionnaire:

TABLE 1.Scores

\begin{tabular}{ll}
\hline \hline Answer Choices & Score \\
\hline & \\
Very Important & 5 \\
Important & 4 \\
Neutral & 3 \\
Less Important & 2 \\
Not Important & 1 \\
\hline \hline
\end{tabular}

\section{Population and Sample}

The population in this study are the investors or the decision makers in the capital market that are domicile in Bandung. Corresponding press release of IDX Bandung branch population recorded the number of investors in the 
Indonesia Stock Exchange in Bandung area to be 8,400 persons as of December 2013. The sampling technique in this research is proportional random sampling to determine the sample size in this study using the formula Slovin. Thus, the samples will be calculated as follows:

$$
\mathrm{n}=\frac{8400}{1+8400(0.1)^{2}}=98.823
$$

This means that in this study the researcher has decided to sample the 100 respondents who are investment managers and individual investors in Bandung.

\section{Validity and Reliability}

Before running the data analysis, we conducted a validity test to determine how valid the instruments are. High and low validity of the instrument indicates the extent to which the data collected does not deviate from the description of the variables studied. Reliability indicates the level or degree of precision, accuracy and precision demonstrated by the measurement instrument. Reliability can also mean the extent to which the measuring instrument can be trusted and reliable. Reliability test was conducted using Cronbach-alpha method. In this study, in order to facilitate and accelerate the process of validity and reliability, the authors used a computerized SPSS software.

\section{Factor Analysis}

The purpose of factor analysis is to define a matrix of data and perform analysis of the correlation between the numbers of variables. Also can be used to estimate the shape and structure of loading and variants of indicators to be observed. a number of variables that are eligible to obtain, activity continued to core processes in factor analysis, namely factoring; This process will extract one or more factors of the variables that have escaped the previous variable test. In factoring, the factor loading selected only those with a value greater than 0.55 because this value is considered to represent real value (Santoso, 2003). If the factor is greater than the cut-off point (0.55) means that these factors represent variables that already exist.

\section{Hypothesis}

The proposed research hypotheses to be tested using a paired sample $t$ test were:

HO $=\mu 1 \leq \mu 2$; Fundamental analysis is nothing more dominant than the technical analysis.

H1 $=\mu 1>\mu 2$; Fundamental analysis is more dominant than the technical analysis.
Basis for a decision on hypothesis testing can be done in a way:

1) If the sig $\leq 0.05$, then Ho is rejected, and $\mathrm{H} 1$ is accepted.

2) If the sig $>0.05$, then Ho is accepted, and $\mathrm{H} 1$ is rejected.

\section{FINDINGS}

There are 100 respondents (investors) in this study, who had been willing to assist in filling out the questionnaire. Determination of respondents by sex consists of two characters that are men and women, Investor men in the study sample were 74 people while the female investors were as many as 26 people. The age groups of 3 categories that are grouped in this study are less than $\leq 27$ year old, 28-35 year old, and investors with over 35 years of age. Distribution based work is more focused on the investment manager as many as 61 respondents while the value of the investment can be divided into three levels, namely at $<50$ million, 50-150 million, and the value of an investment over 160 million. In addition, the investment period is divided into three categories: investment value of $<1$ year, 1-5 years, and the term of the investment over 5 years.

\section{Analysis of Respondents}

The following table will be presented in the form of respondents regarding fundamental analysis techniques as independent variables in this study. The table covers the data presented in the form of scores and the percentage of respondents' assessment of the fundamental analysis in accordance with the choice of answers in the questionnaire.

TABLE 2. Recapitulation of fundamental analysis

\begin{tabular}{llllll}
\hline \hline No & Factors & Score & $\begin{array}{l}\text { Ideal } \\
\text { Score }\end{array}$ & \% & Rank \\
\hline 1 & Macro Economics & 2184 & 2500 & $87,4 \%$ & 4 \\
2 & Industry Analysis & 861 & 1000 & $86,1 \%$ & 6 \\
3 & Profitability Ratio & 1794 & 2000 & $89,7 \%$ & 1 \\
4 & Liquidity Ratio & 1330 & 1500 & $88,7 \%$ & 2 \\
5 & Leverage Ratio & 884 & 1000 & $88,4 \%$ & 3 \\
6 & Market Ratio & 1304 & 1500 & $86,9 \%$ & 5 \\
7 & Efficiency Ratio & 850 & 1000 & $85 \%$ & 7 \\
\multicolumn{7}{l}{ Total } & 9207 & 10500 & & \\
Percentage & $87,7 \%$ & & & \\
\hline \hline
\end{tabular}

According to the results of the above recapitulation, the researchers attempted to rank the fundamental constituent variables based on the percentage of the value 
obtained. It can be seen that the real profitability ratio variable has the highest percentage among other variables that is equal to $89.7 \%$. When the layout is described in the continuum line response to the respondents' assessment of fundamental analysis, it is described based on predetermined criteria. So the calculations in the table show the values obtained i.e. 9207 or $87.8 \%$ of the ideal score is 10500 . Thus Fundamental analysis is a very good category. As for the calculation of the overall summary on technical analysis, variables are presented in the following table:

TABEL 3.Recapitulation of technical analysis

\begin{tabular}{llllll}
\hline \hline No & Factors & Score & $\begin{array}{l}\text { Ideal } \\
\text { Score }\end{array}$ & Rank \\
\hline & & & & & \\
1 & Price Trend & 855 & 1000 & $86,8 \%$ & 3 \\
2 & Market Strength & 862 & 1000 & $87,2 \%$ & 2 \\
3 & Data History & 870 & 1000 & $87,8 \%$ & 1 \\
4 & $\quad$ Volatility & 428 & 500 & $85,6 \%$ & 4 \\
Total & 3015 & 3500 & & \\
Percentage & $86,1 \%$ & & & \\
\hline \hline
\end{tabular}

The table illustrates the responses of respondents regarding Technical Analysis. The results of processing are presented in the table above, it can be seen that the total score for Technical Analysis is 1737. Ideally, the expected score for respondents' answers to the four questions is 2000. The calculations in the table show the values obtained up to 1737 or $86.9 \%$ of the ideal score of 2000. Thus Technical Analysis is another good category.

\section{Validity and Reliability}

The test instrument study of 30 respondents intended to test the validity and reliability of grains of instruments used in the study. Validity test should be done on each of the questions. The results were compared with the count $r$ $r$ which amounted to 0,361 critical. If the count $r>r$ critical it is valid. Here are the results of testing the validity of the factors-factors that influence an investment decision. Reliability test can be performed simultaneously on all the questions. So in this process all the questions that are 25

tested simultaneously for their reliability. If the value of Cronbach Alpha $>0.70$ then it is declared unreliable. Here are the results of a reliability test using SPSS 16.0.

TABLE 4. Reliability

Cronbach's Alpha Item's

0.962

0.963

28

From the above table it can be seen that reliability test results on the 28 items on the questionnaire showed a Cronbach alpha value of $0963>0.7$ which means that the questionnaire is reliable and feasible to circulate among more appropriate samples.

\section{Factor Analysis Fundamental Analysis}

To find out how many new factors that are formed, Eigen valuecan be used. Eigen value is about having a value greater than 1 . Here's a table that describes the factors that are formed and have Eigen value greater than 1 .

TABEL 5.Total variance explained

\begin{tabular}{lrll}
\hline \multicolumn{4}{l}{ Extraction Sum of Squared Loading } \\
\hline Component & Total & \% Variance & Cumulative \\
1. & 7.769 & $36.997 \%$ & $36.997 \%$ \\
2. & 2.170 & $10.333 \%$ & $47.330 \%$ \\
3. & 1.554 & $7.399 \%$ & $54.729 \%$ \\
4. & 1.237 & $5.899 \%$ & $60.618 \%$
\end{tabular}

To know the contents of each of these factors, it can be seen by looking at the value of the load factor (factor loadings). Load factor (factor loadings) showed greater correlation between a variable with factors that are formed. The larger the value of a variable's load factor, the more close the relationship of these variables with the form factor. In load factor, it is necessary to vary max rotation. This rotation is useful to minimize redundancy among the factors, because each factor explains the diversity of each variable origin. The results of fundamental factor analysis that are represented as fundamental variable in the decision consist of Interest 
Rates, Net Profit Margin, ROE, Debt Ratio, Debt to Equity Ratio, DPR, and Total Assets Turnover.

\section{Technical Analysis}

In the results of the total variance explained to technical factors there in only one factor that has the Eigen value greater than 1, with the value of 3.050 and percentage of variance equal to $43574 \%$. The results of the factor analysis on technical factors only form a constituent factor of this variable. The result shows that historic data is technical factor which represents technical variable for investment decision making.

\section{Hypothesis Testing}

Hypothesis test in this research was conducted using paired sample t test to determine the average difference of two variables that were:

TABLE 6. Paired sample T-Test

\begin{tabular}{lllllll}
\hline \hline Pair & $\begin{array}{l}\text { Mea } \\
\mathbf{n}\end{array}$ & $\mathbf{N}$ & $\begin{array}{l}\text { Std } \\
\text { Dev }\end{array}$ & $\begin{array}{l}\text { Corelati } \\
\text { on }\end{array}$ & $\mathbf{T}$ & Sig \\
\hline Fund. & 2.91 & 100 & 0.88 & .404 & -3.623 & .000 \\
\hline \hline
\end{tabular}

The table above shows the exposure data from both samples. Values above show that the average mean of the fundamental variables obtained amounted to 2.91. While the average for Technical variable is equal to 3.26. The correlation in the two variables shows a value of 0404 with $0.000 \mathrm{Sig}$, which means the average correlation between the two variables is strong. Furthermore, as seen previously, the mean value of fundamental variable is smaller than the average value of technical variables, namely $2.91<3.26$. Thus it can be stated that fundamental analysis is not more dominant than technical analysis that means $\mathrm{HO}$ cannot be rejected.

\section{DISCUSSION}

From a series of factor analysis, process to determine the factors (indicators) that are considered by the decision makers in making investment decisions can be summarized as follows. In the fundamental variables formed, four new factors were added which led to the grouping of all the factors in this study so as to represent a major factor in making investment decisions. However, only the first factor that is considered the most influential in the investment decision has the Eigen value of 7769 and this is the largest Eigen value among the three other factors, so that it can be stated that this factor is the most influential factor to become a major factor in investment decision making. The first factor can explain the diversity of the data by $36.997 \%$. This means that the factors bringing the fundamental variables into consideration and influencing investment decisions in this study include the interest rate, the net profit margin, ROE, debt ratio, debt to equity ratio, and the total asset turnover where the indicator is a constituent of the first factor from the results of the factor analysis. In contrast to the results of previous research and by looking at the constituent technical variables in this study, the trend of prices, market forces, historical data, and volatility are found to be the most technical factors considered by the respondents in this study of the historical data. It has been presented in the previous factor analysis that historical data factors have a value stock price data loading factor of 0.641 . This means that $64 \%$ of the indicators can represent technical factors in making investment decisions. So the historical factor data are taken as a major factor in the study of technical variables that can influence the decision makers while making investment.

Through the comparison of the two methods, mean between fundamental and technical variables is found that aims to determine which variables are more dominant and used by decision makers. These results indicate that the hypothesis testing using 2 different tests produced output that is the Sig from $(0.000>0.05)$ and $t$ value count is greater than $t$ table, that is equal to -3.62 . In accordance with previous hypotheses decision if $\operatorname{sig}<0.05$, then $\mathrm{H} 1$ is rejected, and $\mathrm{HO}$ is accepted.

Thus, it can be concluded that in this study the respondents in Bandung as decision makers have to pay more attention to choosing strategies of technical analysis than fundamental analysis in investing. The discovery of the fundamental results being no more dominant than technical results in this study adds to the reference to the investment decision. Technical analysis is emerging and developing, supported by this study and is more considered by individual investors.

\section{CONCLUSION}

This research found that the macro factors, namely interest rates, profitability ratios factors like NPM and the company's ROE, Leverage ratio factor, Dividend Payout ratio and Asset Turnover Values are all factors constituent of fundamental analysis that have role and influence on the investment decision.

In factors of technical variables, it was found that the indicators of Historical Data are technical factors that play a role and influence the investment decision. From the 
data analysis we found that fundamental and technical analyses were proven to be proportionately considered when investors make decisions about investment. None of the analyses is more preferable than other.

\section{REFERENCES}

Aprillianto, B., Wulandari, N., \& Kurrohman, T. 2014. Perilaku Investor saham individual dalam pengambilan keputusan investasi: Studi hermeneutika-kritis. E-Journal Ekonomi Bisnis dan Akuntansi, 1(1): 16-31.

Bodie, Z., Kane, A., Marcus, A.J. 2014. Manajemen portfolio dan Investasi (9th ed). Jakarta, ID: McGraw-Hill Education (Asia) and Salemba Empat (Translator).

Flanegin, F.R., \& Rudd, D.P. 2005. Should investments professors join the "crowd". Managerial Finance, 31(5): $28-37$.

Lawrence, G.J. 2006. Principles of managerial finance (11th ed.). New York, US: Prentice Hall.

Jones, C.P. 2004. Investment analysis and management. New York, US: John Wiley and Sons.

Pring, M.J. 2002. Technical analysis explained: The successful investor's guide to spotting investment trends and turning points. New York, US: McGraw-Hill Professional.

Reilly, F., \& Brown, K. 2003. Investment analysis and portfolio management (7th ed). New York, US: South Western a Division of Thomson Learning.

Sekaran, U. 2006. Research methods for business (Metode penelitian untuk bisnis) (4rth Ed). Jakarta, ID: Penerbit Salemba Empat.

Sugiyono. 2003. StatistikauntukPenelitian. Bandung, ID: CV Alfabeta.

Tandelilin, E. 2010. Portofoliodaninvestasi :Teoridanaplikasi (1st ed.). Yogyakarta, ID: Kanisius.

Lee, Y.J., Wang, G.L., Kao, K.S., Chen, C.Y., \& Zhu, F.P. 2010. The investment behavior decision factors and their effects toward investment performance in the Taiwan stock market. Journal of Global Business Management, 6(2): 1-12.

— This article does not have any appendix. - 